\title{
Knowledge, attitude, and practice on COVID-19 among undergraduate students of B. P. Koirala Institute of Health Sciences, Dharan, Nepal: An online cross-sectional survey
}

\author{
Pandey $\mathrm{KR}^{1 *}$, Panday $\mathrm{DR}^{2}$, Pyakurel $\mathrm{P}^{3}$, Marahatta $\mathrm{S}^{4}$, Rimal $\mathrm{SP}^{5}$, Dali $\mathrm{M}^{6}$, Gyawali $\mathrm{R}^{7}$, Sigdel $\mathrm{R}^{8}$, Bhattarai $\mathrm{N}^{9}$, \\ Limbu N ${ }^{10}$, Rauniar GP ${ }^{11}$
}

\section{*Corresponding author:}

Dr. Karishma Rajbhandari Pandey, Associate Professor, Department of Basic and Clinical Physiology, BPKIHS, Dharan, Nepal.

Email: karishma@bpkihs.edu ORCID

Information about the article:

Received: Jan. 20, 2021

Accepted: May 17, 2021

Published online: July 11, 2021

Cite this article:

Pandey KR, Panday DR, Pyakurel P, Marahatta S, Rimal SP, Dali M, et al. Knowledge, attitude, and practice on COVID-19 among undergraduate students of B. P. Koirala Institute of Health Sciences, Dharan, Nepal: An online cross-sectional survey. Journal of Biomedical Sciences. 2021; $8(1): 15-22$

Publisher

Nepal Health Research Society, Bahundhara -6, Gokarnesowor Municipality, Kathmandu, Nepal

eISSN 2382-5545, ISSN 2676-1343 (Print)

(C) The Author(s). 2021

Content licensing: CC BY 4.0

\begin{abstract}
Background

COVID-19, a global health crisis of the $21^{\text {st }}$ century, has threatened possibly every aspect of human life. Since the pandemic is not yet over, this study was carried out among undergraduate students of a medical institute in Nepal to assess and boost their KAP status on the disease.
\end{abstract}

\section{Material and methods}

It was an online cross-sectional census survey performed among consenting undergraduate healthcare students of BPKIHS. A self-made and validated questionnaire assessing KAP on COVID-19 was prepared in Google form and distributed online among target students. The study population was 745. Both descriptive and inferential analysis of the data was performed. Student's T-Test and one-way ANOVA were applied for which level of statistical significance was kept at $\mathrm{p}<0.05$.

\section{Results}

Ninety-six students participated in a pilot-study (Cronbach $\alpha=0.792$ ). The response rate was $76.27 \%$. Most participants (76.76\%) were from Nepal. The male/female ratio was 0.76. Most (59.2\%) had not participated in such studies before. For 93.54\%, the source of information was the internet. Assessed by questionnaire, right Knowledge $(\mathrm{n}=16)$ was $85.06 \% \pm 8.81 \%$; right Attitude $(n=6)$ was $65.00 \% \pm$ 16.16 and right Practice $(n=6)$ was $82.88 \% \pm 8.50 \%$. Male were more knowledgeable about the disease $(p=0.011)$. However, females secured higher in practical aspects $(\mathrm{p}=0.000)$. Indian students possessed better knowledge $(\mathrm{p}=0.005)$ and a better attitude $(\mathrm{p}=0.033)$. MBBS students had better knowledge $(\mathrm{p}=0.000)$, but Nursing students secured higher in Practice ( $\mathrm{p}=0.012)$. Attitude is better in the earlier years $(\mathrm{p}=0.045)$.

\section{Conclusion}

We assessed KAP related to COVID-19 via score among healthcare undergraduate students. Different co-factors do impact students’ overall KAP status.

Keywords

Attitude, COVID-19, knowledge, practice, undergraduate 


\section{Background}

COVID-19 is a relatively new infectious disease caused by a novel coronavirus named 'Severe Acute Respiratory Syndrome Coronavirus 2' (SARS-CoV-2) [1]. It spreads by breathing in the virus if one is within proximity of someone who has the disease or touching a contaminated surface followed by eyes, nose, or mouth [2, 3, 4].

It has impacted all sectors of human life, including the educational system worldwide [5]. It has led to the neartotal closures of schools, universities and colleges [6]. It will not be an exaggeration when we say that we live amidst "potentially one of the toughest times of human history" with a significant threat to the much-earned asset of human civilization, the education system [6, 7].

Though it has threatened possibly every aspect of modern human life for more than a year, it has still not been effectively contained as yet. When this study was being planned, no precise treatment or vaccine was registered to work. Additionally, there was a nationwide lock-down, so all the students of this medical institute had gone to their homes: mostly different parts of Nepal and neighboring India. Therefore, this online study was planned to assess and raise the knowledge, attitude, and practice (KAP) status of the potential health care manpower of the near future (the undergraduate health care professionals) of the institute.

\section{Material and methods}

\section{Study design and the participants}

It was a cross-sectional survey using a self-developed online questionnaire prepared in Google form. The study was conducted in an online platform from 1st of July to 30th November 2020 under the initiatives of coordinators and deputy coordinators of medical, dental and nursing programs of BPKIHS (B.P. Koirala Institute of Health Sciences), Nepal;. Others involved were experts on the topic "COVID-19". The focused group of the study were undergraduate medical, dental and nursing students of BPKIHS.

\section{Questionnaire design and validity}

The questionnaire consisted of two parts: Demographics and KAP Questionnaire. Demographic variables included Name, Sex, Stream (medical/ dental/nursing), Year of study in BPKIHS, Area of residence and Source of information about COVID-19. KAP questionnaire (Table 1) consisted of 16 questions on Knowledge, six questions on Attitude, and nine questions on Practice related to COVD-19 with closedended 'yes', 'no' or 'can't say' response options.

Pretesting of the questionnaire was done among $10 \%$ of the health sciences students. These students were later not included in the final survey. Face and content validity were established by discussing with subject experts. Reliability of the study was done by analyzing the pre-tested questionnaire and questionnaire was validated by using Cronbach' alpha (0.795)
A pilot study was done on 96 students from the first two years of BDS. Based on suggestions made by subject and linguistic experts, few modifications were brought in the questionnaires and applied to the rest of the group, which were 649 in number. Out of which, only 495 undergraduates filled the Google form.

\section{Table 1: Questionnaire on knowledge, attitudes, and practice towards COVID-19}

Knowledge of the participants regarding COVID -19

K1. Virus is the cause of COVID 19 infection.

K2. Fever is the most common symptom of COVID-19.

K3. Runny nose, sneezing and diarrhea are symptoms of COVID-19.

K4. Currently there is no effective cure for COVID-19.

K5. Early symptomatic and supportive treatment help most patients recover from the infection.

K6. All people infected with COVID-19 become seriously ill.

K7. Mortality rate of people infected with COVID-19 is higher among Elderly, Diabetic and hypertensive people.

K8. COVID 19 spreads by eating or contacting domestic animals.

K9. COVID-19 virus spreads via respiratory droplets of infected individuals.

K10. Wearing a surgical mask is an effective preventive measure for COVID-19.

K11. WHO handwashing method is a preventive measure for COVID-19.

K12. Avoiding crowded places such as cinema halls, use of public transportation, restaurants is a measure to prevent COVID-19.

K13. Children and young adults need not take measures to prevent infection by COVID-19.

K14. Quarantine and Isolation means same.

K15. Time period for quarantine is four days.

K16. Once infected with COVID-19, the individual is immune to disease

Attitude of the participants towards COVID-19

A1. COVID-19 will be controlled in future.

A2. Everyone with COVID-19 infection will die of the disease.

A3. "Lockdown" is an effective measure to control the transmission.

A4. Self-protection measures are also for the protection of the others.

A5. Because of COVID-19, life would never be the same again as before.

A6. The "New-normal" set in with COVID-19 is adaptable.

Practice of the participants towards COVID-19

P1. In recent days, have you gone to any crowded place?

P2. Do you always wear mask while leaving home?

P3. Do you wash hands by "WHO hand-washing technique"?

P4. Do you practice social distancing?

P5. Do you cover your nose with tissue or handkerchief or fold your arms around your nose while sneezing?

P6. Do you dispose surgical mask once soiled with moisture or after sneezing?

P7. Do you avoid touching "T Zone" of your face with your

hands?

P8. Do you regularly clean frequently touched objects and surfaces?

P9. Do you practice mindfulness and stress relief?

\section{Data collection}

The questionnaire was prepared in Google form. Before sending our online Google form (questionnaire), we had formally introduced about the study to the batch at the end of one of their regular online theory classes and for some batches where no online class was being conducted, we 
arranged a meeting after circulating a message through Class Representatives of the batch. Then we sent the questionnaire-links through different free online platforms at our disposal, namely, in Dudal chat box/ Google meet/ Zoom/ WhatsApp/ Viber and email and requested the students to fill it real-time. For "one institute's Roll number, one entry" was counted. Response in "Google form analytics" was checked every day, and emails to nonresponders were sent once more. Then response in the Google forms was exported in excel sheet as ".csv" data.

\section{Inclusion criteria}

Any undergraduate students of BPKIHS from any of the following streams viz., MBBS, BDS, or B.Sc. Nursing were eligible to participate in this study if they were willing to give informed consent.

\section{Exclusion Criteria}

Although currently studying in the health science undergraduate program, any subject outside the institute was not included in the study.

\section{Sample size calculation}

This study was done to determine the KAP status of COVID-19 among undergraduate students of the institute. Hence a census method was employed. The total number of undergraduate students were MBBS (414), BDS (196), BSc. Nursing (135). This summed to a total sample of 745.

\section{Data management and statistical analysis}

Statistical analysis of the data (both Descriptive and Inferential) was performed using a Google data sheet converted into a Microsoft Excel worksheet and using the SPSS version 11.5 (SPSS INC., Chicago, IL, USA). For inferential statistics, the statistical significance level was set at $\mathrm{p}<0.05$ and was derived by appropriate statistical tests, namely Student's T-Test and one-way ANOVA. By consensus of the study investigators, the correct assumed answer was assigned "one point", and other incorrect ones were assigned "zero point".

\section{Ethical committee approval}

Ethical approval was obtained from the Institutes' Review Committee (IRC). The reference number of the Ethical Committee Letter issued is 147/077/078. Before online participation, participants gave informed consent.

\section{Results}

The response rate of this study was $76.27 \%$. The, participation from different batches of students were overwhelming (Table 2). Response rate of 3rd year medical students was maximum however, the overall respondents' percentage was maximum for $1^{\text {st }}$ year medical students. The response rate was minimal from the dental $3^{\text {rd }}$ year students whereas, the overall respondents rate was lowest from the 2nd year nursing students.

\begin{tabular}{|c|c|c|c|c|}
\hline $\begin{array}{l}\text { Stream of } \\
\text { Participating } \\
\text { Student }\end{array}$ & $\begin{array}{l}\text { Total } \\
\text { students }\end{array}$ & $\begin{array}{l}\text { Respondents } \\
\text { (N) }\end{array}$ & $\begin{array}{l}\text { Response } \\
\text { rate }(\%)\end{array}$ & $\begin{array}{l}\text { Overall } \\
\text { Respondent's } \\
\text { percentage } \\
(\%)\end{array}$ \\
\hline BDS-3rd year & 41 & 26 & 63.41 & 5.25 \\
\hline BDS-4th year & 61 & 41 & 67.21 & 8.28 \\
\hline $\begin{array}{l}\text { Bsc-Nursing-1st } \\
\text { year }\end{array}$ & 39 & 29 & 74.35 & 5.86 \\
\hline $\begin{array}{l}\text { Bsc-Nursing-2nd } \\
\text { year }\end{array}$ & 25 & 23 & 92 & 4.65 \\
\hline $\begin{array}{l}\text { Bsc-Nursing-3rd } \\
\text { year }\end{array}$ & 40 & 35 & 87.5 & 7.07 \\
\hline $\begin{array}{l}\text { Bsc-Nursing-4th } \\
\text { year }\end{array}$ & 29 & 25 & 86.2 & 5.05 \\
\hline MBBS-1st year & 103 & 89 & 86.4 & 17.98 \\
\hline MBBS-2nd year & 103 & 66 & 64.07 & 13.33 \\
\hline MBBS-3rd year & 94 & 85 & 90.4 & 17.17 \\
\hline MBBS-4th year & 114 & 76 & 66.66 & 15.35 \\
\hline Total & 649 & 495 & 76.27 & 100 \\
\hline
\end{tabular}

\begin{tabular}{lcc}
\hline $\begin{array}{l}\text { Table 3: Source of COVID-19 information for the } \\
\text { students }\end{array}$ \\
\hline Source & $\mathbf{N}(\mathbf{4 9 5 )}$ & $\mathbf{\%}$ \\
Internet & 463 & 93.54 \\
Mass media & 377 & 76.16 \\
Family and friends & 330 & 66.67 \\
Others not specified & 97 & 19.60 \\
\hline
\end{tabular}

The source of information regarding COVID-19 is shown in Table 3. For most of them internet was the primary source of their COVID-related information, followed by mass media and family and friends.

\section{Table 4: Knowledge of the students on COVID-19} Knowledge on COVID-19 Correct

response (\%)

K12. Avoiding crowded places such as cinema halls, 494 (99.8) use of public transportation, restaurants is a measure to prevent COVID-19.

K1. Virus is the cause of COVID-19 infection. 492 (99.4)

K9. COVID-19 virus spreads via respiratory droplets 489 (98.8) of infected individuals,

K11. "WHO hand washing" technique is a preventive 487 (98.4) measure for COVID-19.

K7. Mortality rate of people infected with COVID-19 482 (97.4) is higher among Elderly, Diabetic and hypertensive people.

K15. Time period for quarantine is four days. 479 (96.8)

K5. Early symptomatic and supportive treatment help 475 (96.0) most patients recover from the infection.

K6. All persons with COVID-19 become serious ill. 469 (94.7)

K14. Quarantine and Isolation means same. 452 (91.3)

K2. Fever is the most common symptom of COVID- 449 (90.7) 19.

K4. Currently there is no effective cure for COVID- 438 (88.5) 19.

K10. Wearing a surgical mask is an effective 411 (83.0) preventive measure of COVID-19.

K13. Children and young adults need not take 402 (81.2) measures to prevent from infection of COVID19.

K8. COVID-19 spreads by eating or contacting 355 (71.7) domestic animals.

K16. Once infected with COVID-19, the individual is 233 (47.1) immune to disease. 
K3. Runny nose, sneezing and diarrhoea are the most 130 (26.3) common symptoms of COVID-19.

Out of 16 questions asked on knowledge related to COVID19 , the students possessed adequate knowledge (76\% and above) in 13 different questions. The knowledge level was moderate (51-75\%) for K8. Regarding the knowledge level for K16 and K3, it was inadequate (50\% and below) (Table 4).

\begin{tabular}{|c|c|c|c|c|}
\hline \multicolumn{5}{|c|}{ Table 5: Attitude of the Students towards COVID-19 } \\
\hline & $\begin{array}{l}\text { Attitude towards } \\
\text { COVID-19 }\end{array}$ & Yes & No & Can't say \\
\hline A1. & $\begin{array}{l}\text { COVID-19 will be } \\
\text { controlled in future. }\end{array}$ & $280(56.6)$ & $9(1.8)$ & $\begin{array}{l}206(41.6) \\
\text { (Correct } \\
\text { response) }\end{array}$ \\
\hline A2. & $\begin{array}{l}\text { Everyone with } \\
\text { COVID-19 infection } \\
\text { will die of the disease. }\end{array}$ & $2(0.4)$ & $\begin{array}{l}476(96.2) \\
\text { (Correct } \\
\text { response) }\end{array}$ & $17(3.4)$ \\
\hline A3. & $\begin{array}{l}\text { "Lockdown" is an } \\
\text { effective measure to } \\
\text { control the } \\
\text { transmission. }\end{array}$ & $\begin{array}{l}303(61.2) \\
\text { (Correct } \\
\text { response) }\end{array}$ & $94(19.0)$ & $98(19.8)$ \\
\hline A4. & $\begin{array}{l}\text { Self-protection } \\
\text { measures are also for } \\
\text { the protection of the } \\
\text { others. }\end{array}$ & $\begin{array}{l}489(98.8) \\
\text { (Correct } \\
\text { response) }\end{array}$ & $2(0.4)$ & $4(0.8)$ \\
\hline A5. & $\begin{array}{l}\text { Because of COVID- } \\
19 \text {, life would never } \\
\text { be the same again as } \\
\text { before. }\end{array}$ & $151(30.5)$ & $180(36.4)$ & $\begin{array}{l}164(33.1) \\
\text { (Correct } \\
\text { response) }\end{array}$ \\
\hline A6. & $\begin{array}{l}\text { The "New-normal" set } \\
\text { in with COVID-19 is } \\
\text { adaptable. }\end{array}$ & 295 (59.6) & 59 (11.9) & $\begin{array}{l}141(28.5) \\
\text { (Correct } \\
\text { response) }\end{array}$ \\
\hline
\end{tabular}

Maximum students (98.8\%) possessed the correct attitude that self-protection measures are also for the protection of others. Again, most of the students correctly disagreed that everyone with COVID-19 infection will die of the disease. Maximum (41.6\%) students were skeptic about the disease being controlled in near future. The least \% of students (30.5\%) bear the attitude that life will not be same as before, however $59.6 \%$ had the attitude that the new normal set in due to COVID-19 is adaptable (Table 5).

Maximum students responded of practicing the correct measures to prevent COVID-19 infection such as covering nose while sneezing, wearing mask, social distancing and washing hands with soap water (Table 6). Mindfulness and stress relief were among the least methods practiced by the students.

\begin{tabular}{|c|c|c|}
\hline \multicolumn{3}{|c|}{ Table 6: Practice of the Students on COVID-19 } \\
\hline & Practice on COVID-19 & $\begin{array}{l}\text { Correct } \\
\text { response N (\%) }\end{array}$ \\
\hline P5. & $\begin{array}{l}\text { Do you cover your nose with tissue or } \\
\text { handkerchief or fold your arms around your } \\
\text { nose while sneezing? }\end{array}$ & $487(98.4)$ \\
\hline $\mathrm{P} 2$. & $\begin{array}{l}\text { Do you always wear mask while leaving } \\
\text { home? }\end{array}$ & $472(95.4)$ \\
\hline
\end{tabular}

\begin{tabular}{|c|c|c|c|}
\hline P4. & \multicolumn{2}{|c|}{ Do you practice social distancing? } & 465 (93.9) \\
\hline P3. & \multicolumn{2}{|c|}{$\begin{array}{l}\text { Do you wash hands by "WHO hand- } \\
\text { washing technique”? }\end{array}$} & $443(89.5)$ \\
\hline P6. & \multicolumn{2}{|c|}{$\begin{array}{l}\text { Do you dispose surgical mask once soiled } \\
\text { with moisture or after sneezing? }\end{array}$} & $424(85.7)$ \\
\hline P7. & \multicolumn{2}{|c|}{$\begin{array}{l}\text { Do you avoid touching "T Zone" of your } \\
\text { face with your hands? }\end{array}$} & $373(75.4)$ \\
\hline P8. & \multicolumn{2}{|c|}{$\begin{array}{l}\text { Do you regularly clean frequently touched } \\
\text { objects and surfaces? }\end{array}$} & 364 (73.5) \\
\hline P1. & \multicolumn{2}{|c|}{$\begin{array}{l}\text { In recent days, have you gone to any } \\
\text { crowded place? }\end{array}$} & 349 (70.5) \\
\hline P9. & \multicolumn{2}{|c|}{$\begin{array}{l}\text { Do you practice mindfulness and stress } \\
\text { relief? }\end{array}$} & $324(65.5)$ \\
\hline \multicolumn{4}{|c|}{$\begin{array}{l}\text { Table 7: Mean Score of correct knowledge, attitude } \\
\text { and practice on COVID-19 among UG students of } \\
\text { BPKIHS }\end{array}$} \\
\hline \multicolumn{2}{|c|}{ Variables } & \multicolumn{2}{|c|}{ Mean \pm SD (same in percentage) } \\
\hline \multicolumn{2}{|c|}{ Knowledge (n=16) } & \multicolumn{2}{|c|}{$13.61 \pm 1.4(85.06 \pm 8.81)$} \\
\hline \multicolumn{2}{|c|}{ Attitude $(n=6)$} & \multicolumn{2}{|c|}{$3.90 \pm 0.97(65 \pm 16.16)$} \\
\hline \multicolumn{2}{|c|}{ Practice $(n=9)$} & \multicolumn{2}{|c|}{$7.46 \pm 1.36(82.88 \pm 8.50)$} \\
\hline
\end{tabular}

The average percentage scored by the undergraduate students in knowledge, attitude and practice were $85.06 \%$, $65 \%$ and $82.88 \%$ respectively (Table 7 ).

Comparison of COVID-19 related correct mean KAP scores between different groups were done. The male/female ratio of the responders was $0.76(214 / 281)$. Male were more knowledgeable about the disease compared to females $(p=0.011)$. However, females secured higher in practical aspects $(\mathrm{p}<0.01)$.

Majority (380/495) of the students were from Nepal. Rest (114/495) were from India. One student mentioned "other than above mentioned" for the "area of residence”. Based on location, Indian students possessed better knowledge $(\mathrm{p}<0.01)$ and better attitude $(\mathrm{p}<0.05)$ towards the disease compared to Nepalese students.

Most responders (293/495) had not participated in any COVID-19 related studies before. History of participation in previous COVID related studies significantly increased only the knowledge aspect about the disease $(\mathrm{p}<0.01)$.

The majority (437/495) of the study population said no family member, including themselves, had suffered the condition when this study was conducted. Those students with any of their family members infected by COVID-19 in the past had a poorer attitude towards the disease $(\mathrm{p}<0.05)$. MBBS students had better knowledge about the disease $(\mathrm{p}<0.01)$. However, B.Sc. Nursing students scored higher $(p<0.05)$ when correct practical aspects of COVID-19 were compared. Comparing KAP across the academic years, we found that attitude towards the disease was better in the earlier years $(\mathrm{p}<0.05)$ (Table 8$)$.

\section{Discussion}

The present research was necessary because past KAP studies have shown that knowledge, attitude, and Practice are related [8, 9] and are essential and effective elements to control and prevent public health emergency conditions such as COVID-19. Being equipped with necessary KAP 


\begin{tabular}{|c|c|c|c|c|c|c|c|c|}
\hline \multirow[t]{2}{*}{ Variant } & Categories & Number (\%) & $\begin{array}{l}\text { Mean knowledge } \\
\pm \text { SD }\end{array}$ & p value & $\begin{array}{l}\text { Mean attitude } \\
\pm \text { SD }\end{array}$ & p value & $\begin{array}{l}\text { Mean practice } \pm \\
\text { SD }\end{array}$ & p value \\
\hline & Male & 214 (43.23) & $13.79 \pm 1.33$ & $0.011^{*}$ & $3.81 \pm .94$ & $0.067^{\times}$ & $7.10 \pm 1.45$ & $0.000^{\dagger}$ \\
\hline Sex & Female & 281 (56.77) & $13.46 \pm 1.46$ & & $3.97 \pm .99$ & & $7.74 \pm 1.22$ & \\
\hline Area of & Nepal & 380 (76.77) & $13.50 \pm 1.43$ & $0.005^{\dagger}$ & $3.84 \pm 1.02$ & $0.033^{*}$ & $7.45 \pm 1.35$ & $0.516^{\times}$ \\
\hline \multirow[t]{2}{*}{ Residence } & India & 114 (23.03) & $13.96 \pm 1.28$ & & $4.11 \pm .77$ & & $7.51 \pm 1.40$ & \\
\hline & Other & $1(0.20)$ & $15.00 \pm 0.00$ & & $4.00 \pm 0.00$ & & $6.00 \pm 0.00$ & \\
\hline $\begin{array}{l}\text { Participation } \\
\text { in any }\end{array}$ & Yes & $202(40.81)$ & $13.87 \pm 1.34$ & $0.000^{\dagger}$ & $3.93 \pm .96$ & $0.628^{\times}$ & $7.48 \pm 1.37$ & $0.876^{\times}$ \\
\hline $\begin{array}{l}\text { COVID-19 } \\
\text { study } \\
\text { before? }\end{array}$ & No & 293 (59.19) & $13.42 \pm 1.43$ & & $3.88 \pm .98$ & & $7.46 \pm 1.36$ & \\
\hline \multirow{2}{*}{$\begin{array}{l}\text { Any of the } \\
\text { family } \\
\text { infected by } \\
\text { COVID-19? }\end{array}$} & Yes & 58 (11.72) & $13.62 \pm 1.19$ & $0.952^{\times}$ & $3.60 \pm .91$ & $0.012^{*}$ & $7.39 \pm 1.42$ & $0.669^{\times}$ \\
\hline & No & 437 (88.28) & $13.60 \pm 1.44$ & & $3.94 \pm .97$ & & $7.47 \pm 1.35$ & \\
\hline \multirow[t]{3}{*}{ Stream } & BSc Nursing & 112 (22.63) & $13.11 \pm 1.62$ & $0.000^{\dagger}$ & $3.87 \pm 1.04$ & $0.933^{\times}$ & $7.74 \pm 1.21$ & $0.012^{*}$ \\
\hline & BDS & 67 (13.54) & $13.73 \pm 1.35$ & & $3.91 \pm 1.05$ & & $7.65 \pm 1.34$ & \\
\hline & MBBS & 316 (63.84) & $13.75 \pm 1.30$ & & $3.91 \pm .93$ & & $7.33 \pm 1.40$ & \\
\hline \multirow{4}{*}{$\begin{array}{l}\text { Year of } \\
\text { study }\end{array}$} & First year & $118(23.84)$ & $13.57 \pm 1.56$ & $0.115^{\times}$ & $4.05 \pm .85$ & $0.045^{*}$ & $7.42 \pm 1.44$ & $0.458^{\times}$ \\
\hline & Second year & $89(17.98)$ & $13.86 \pm 1.28$ & & $3.94 \pm .96$ & & $7.49 \pm 1.34$ & \\
\hline & Third year & 146 (29.49) & $13.67 \pm 1.31$ & & $3.93 \pm .98$ & & $7.60 \pm 1.28$ & \\
\hline & Fourth year & 142 (28.69) & $13.41 \pm 1.44$ & & $3.72 \pm 1.05$ & & $7.35 \pm 1.38$ & \\
\hline
\end{tabular}

${ }^{\times} \mathrm{p}>0.05,{ }^{*} \mathrm{p}<0.05,{ }^{\dagger} \mathrm{p}<0.01$

assures appropriate information for readiness against pandemic situations mitigates panic and spreads a positive perception among the participants [7]. With this background, the study's uniqueness was in being the first of its kind focused on Nepalese undergraduate health-science students, who have direct involvement with the disease soon if the incidence of the disease goes unchecked. Besides, they are not only the future work pillars against COVID-19 but also spokespersons of the disease. Therefore, it will help disseminate the right KAP to the relatively naïve public and their family and senior and fellow junior colleagues with whom they have to work hand in hand.

\section{Source of information on COVID-19}

In our study, the internet was the most common source of COVID-19 related information. Similar was the experiences of most other studies. However, direct information reaching via WHO, CDC, Ministry of Health, friends, and mass media was another essential source of facts and information in many other studies $[7,8,10,11,12]$.

\section{KAP status on COVID-19}

Regarding knowledge of COVID-19, the majority of undergraduates had good knowledge ( $>80 \%$ Table 7 ) about the disease (causative agent, mode of transmission, incubation period, most common clinical presentation, preventive measures, treatment modalities and high-risk groups). These findings agree with other studies done elsewhere in different study groups [7, 10, 13, 14].

Regarding the level of students' perception towards preventive measures and reaction, if they developed COVID-19, most students (around 65\%, Table 7) had a correct attitude towards the disease. However, the response varied mainly to the statements: "The disease will be controlled in future" and "Life will be the same as before the disease outbreak". However, studies done elsewhere in different study groups had shown the correct score regarding attitude towards the disease to be mainly more significant than $90 \%[7,8,10,13,14]$.

Regarding the level of protective practice, $>90 \%$ of our students confirmed exercising positive preventive measures such as covering their nose with tissues or handkerchiefs or folding arms around their nose while sneezing, wearing masks when they went outdoors maintaining social distance (Table 6). However, the overall score of our undergraduate students in proactive practice was around 83\% (Table 7) and the least precautionary areas rehearsed were 'mindfulness' and 'stress relief practices' (Table 6). Similar findings were obtained in other studies as well $[7,8,10]$.

\section{Effect of gender in KAP in COVID-19}

Our study found that males had a significantly high score on knowledge while females secured substantially better practice (Table 8). Opposite to this finding, other studies have reported that females do better in terms of both knowledge and practice [7, 8, 14]. In our study, females also secured more scores in attitude, but the finding was not statistically significant. Whereas, in Chinese research, females performed better than males in terms of attitude [7]. Nonetheless, in a study done in Baghdad, there was no difference in any component of KAP on COVID-19 concerning gender [15].

\section{Effect of locality in KAP status in COVID-19}

In our study, the Indian students significantly scored better in terms of correct knowledge and attitude towards the disease when compared to Nepalese students (Table 8). Most students during lockdown were in their homes during the conduction of this study. It may point out that the 
dissemination of correct information via different portals, mainly the internet and mass media (Table 3), may be impacted by locality. It may designate greater responsibility of these portals in spreading COVID related information. Other aspects like parental education and economy are among many factors that may also have impacted this finding.

\section{KAP status concerning academic program and year of study}

In our study, medical students scored higher for knowledge regarding COVID-19 than dental and nursing students (Table 8). Though statistically not significant, similar were the findings of the studies done elsewhere among health workers $(\mathrm{N}=1357$ doctors $=38.56 \pm 3.31$; nurses $=37.85 \pm$ 2.63; paramedics $=36.72 \pm 4.82)[9,16]$. It could be because of more first-hand training in clinical and community postings among medical students, which catered them a sense of obligations and responsibilities to fight against the pandemic as future doctors [16]. However, our nursing students scored better in practice among all the streams (Table 8). This could be related to early exposure and training of nursing students to a hospital set-up, which led them to acquire and excel more in practical skills.

Our study also uniquely revealed that attitude towards the disease deteriorates over the years among health care students.

\section{Other factors affecting COVID-19 and KAP status}

Students who had earlier participated in COVID-19 related studies had significantly better knowledge about the disease (Table 8). It, beyond doubt, has highlighted the importance of such studies. Those students who themselves or any of their family members had a history of contracted infection had significantly less positive attitudes towards the disease, which could be related to the stress and bad experience during the period. It is an alarming and worrisome finding. It needs further elaboration in the studies to come.

\section{Conclusion}

We, thus, assessed Knowledge, Attitude and Practice related to COVID-19 via score among healthcare undergraduate students of the institute. Gender, previous exposure to the disease directly or indirectly, participation in previous similar research, stream of the student and year of education can all potentially impact students' overall COVID-19 related KAP status. Therefore, we recommend incorporating these factors by local health policy developers to bring plans on awareness and training campaigns to undergraduate students against COVID-19 and if similar other public health emergencies occur in the future.

\section{Limitation and future scope of the study}

Our survey undoubtedly had few avoidable and few unavoidable limitations. First, pretesting of the questionnaire was carried out only among dental students of first and second years (relatively homogenous population). The piloting sample should have been randomized and stratified, which was, in fact, possible. Internal validity might have suffered. Unlike Knowledge, 'Practice' is better assessed by subjective observation, which was not possible in our case. How accurate is it to consider 'Practice' by real-life practice-related questions sans knowledge like we did, may be a subject of discussion. Again, ideally, 'attitude' is assessed by scaling answer options, which, again, we could not follow for some practical reasons.

\section{Relevance of the study}

Our study has skewed the KAP status of the participants towards a better outcome. In the situation where the country is facing problems with the availability of the vaccine, the enhanced KAP status of the disease will help them prevent from the deadly stubborn virus. Once published whole audience could reap the benefit by being aware of the protective strategies outlined in the result section.

\section{Abbreviations}

B. P. Koirala Institute of Health sciences (BPKIHS), Bachelor in Dental Surgery (BDS), Bachelor in Medicine Bachelor in Surgery (MBBS), Coronavirus disease of 2019 (COVID-19), Institutes' Review Committee (IRC), Intelligent Quotient (IQ), Knowledge, Attitude and Practice (KAP), Nursing: Bachelor in Nursing Sciences (B.Sc.), Severe Acute Respiratory Syndrome Coronavirus 2' (SARS-CoV-2).

\section{Acknowledgments}

The study team deeply appreciate the support and guidance of Rector Sir, Prof. Dr. Guru Khanal Sir, Dean Academic Sir, Prof. Dr. Shivendra Jha Sir and Assistant Dean Academics Dr. Ajay Yadav Sir.

We humbly appreciate the involvement of faculties namely Dr. Nidesh Sapkota Sir, Additional Professor, Department of Psychiatry and Dr. Deebya Raj Mishra Sir, Associate Professor, Department of Pulmonary, Critical and Sleep Medicine for graciously being a part of the team in the Webinar organized on $31^{\text {st }}$ Oct 2020.

We especially acknowledge, Mr. D.D. Baral Sir, Assistant Professor, Department of Community Medicine and School of Public Health, for his unconditional support and guidance in suggesting us the right statistical tool, without which all data would be meaningless.

Also, we'd wish to express our gratitude to Prof. Dr. Jyotsana Rimal ma'am for sharing her expertise and guiding us with the questionnaire.

Lastly, we would like to thank all the undergraduate students for participating in this research.

\section{Authors' contribution}

a. Study planning: KRP, DRP, PP, SM, SPR, MD, RG, RS, NB, NL, GPR 
b. Data collection: KRP, SM, SPR, MD, RG, RS

Data analysis/ interpretation: KRP, DRP, PP, SM, SPR, MD, RG, RS

c. Manuscript writing: KRP, DRP

d. Manuscript revision: KRP, DRP, PP, SM, SPR, MD, RG, RS, NB, NL, GPR

e. Final approval: KRP, DRP, PP, SM, SPR, MD, RG, RS, NB, NL, GPR

f. Agreement to be accountable for all aspects of the work: KRP, DRP, PP, SM, SPR, MD, RG, RS, NB, NL, GPR

\section{Funding}

No funding was obtained for this study.

\section{Availability of data and materials}

All data underlying the results are available as part of the article, and no additional source data are required separately as additional material for this research.

\section{Competing interests}

None declared.

\section{Publisher's Note}

NHRS remains neutral with regard to jurisdictional claims in published maps and institutional affiliations.

The publisher shall not be legally responsible for any types of loss, actions, claims, proceedings, demand or costs or damages whatsoever or howsoever caused arising directly or indirectly in connection with or arising out of the use of this material.

\section{Author information}

${ }^{1}$ Dr. Karishma Rajbhandari Pandey, Associate Professor, Department of Basic and Clinical Physiology ORCID

${ }^{2}$ Dr.Dipesh Raj Panday,Assistant Professor, Department of Clinical Pharmacology and Therapeutic ORCID

${ }^{3}$ Dr.Prajjwal Pyakurel, Assistant Professor School of Public Health and Community Medicine ORCID

${ }^{4}$ Dr.Suchana Marahatta, Associate Professor Department of Dermatology and Venereal Diseases ORCID

${ }^{5}$ Dr.Surya Prasad Rimal, Assistant Professor Department of Obstetrics and Gynecology ORCID

${ }^{6}$ Dr.Mamta Dali, Associate Professor Department of Pedodontics, College of Dental Surgery ORCID

${ }^{7}$ Dr.Rajesh Gyawali, Associate Professor Department of Orthodontics, College of Dental Surgery ORCID

${ }^{8}$ Mrs. Rambha Sigdel, Assistant Professor Community Health Nursing ORCID

${ }^{9}$ Dr.Narayan Bhattarai, Additional Professor Department of Microbiology ORCID

${ }^{10}$ Prof. Dr. Nirmala Limbu, Professor, Department of Basic and Clinical Physiology ORCID

${ }^{11}$ Prof. Dr. GP Rauniar, Professor, Department of Clinical Pharmacology and Therapeutic, ORCID
All authors are affiliated to B.P. Koirala Institute of Health Sciences (BPKIHS), Dharan, Nepal.

\section{References}

1. Huang C, Wang Y, Li X, Ren L, Zhao J, Hu Y, et al. Clinical features of patients infected with 2019 novel coronavirus in Wuhan, China. The Lancet [Internet]. 2020 Feb; 395(10223):497506.

http://dx.doi.org/10.1016/S0140-6736(20)30183$\underline{5}$

2. Lee N, Hui D, Wu A, Chan P, Cameron P, Joynt $\mathrm{GM}$, et al. A major outbreak of severe acute respiratory syndrome in Hong Kong., N. Engl. J. Med. 2003 May; 348(20):1986-1994. https://doi.org/10.1056/NEJMoa030685

3. Assiri A, Al-Tawfiq JA, Al-Rabeeah AA, AlRabiah FA, Al-Hajjar S, Al-Barrak A, et al. Epidemiological, demographic, and clinical characteristics of 47 cases of Middle East respiratory syndrome coronavirus disease from Saudi Arabia: a descriptive study. Lancet. Infect. Dis. 2013 Sep; 13 (9):752-61.

https://doi.org/10.1016/S1473-3099(13)70204-4

4. Anfinrud P, Stadnytskyi V, Bax CE, Bax A. Visualizing speech-generated oral fluid droplets with laser light scattering. N. Engl. J. Med. 2020 May; 382 (21):2061-63. https://doi.org/10.1056/NEJMc2007800.

5. Aristovnik A, Keržič D, Ravšelj D, Tomaževič $\mathrm{N}$, Umek L. Impacts of the COVID-19 pandemic on life of higher education students: a global perspective. Sustainability. 2020; 12(20):8438. https://doi.org/10.3390/su12208438

6. Dawadi S, Giri R, Simkhada. Impact of COVID19 on the education sector in Nepal - challenges and coping strategies. Sage Submissions. 2020; 1-16. https://doi.org/10.31124/advance.12344336.v1

7. Peng Y, Pei C, Zheng Y, Wang J, Zhang K, Zheng Z. et al. A cross-sectional survey of knowledge, attitude and practice associated with COVID-19 among undergraduate students in China, BMC Public Health. 2020 Aug; 20: 1292. https://doi.org/10.1186/s12889-020-09392-z.

8. Zhong BL, Luo W, Li HM, Zhang QQ, Liu XG, $\mathrm{Li}$ WT. et al. Knowledge, attitudes, and practices towards COVID-19 among Chinese residents during the rapid rise period of the COVID-19 outbreak: a quick online cross-sectional survey. Int. J. Biol. Sci. 2020; 16(10): 1745-52. https://doi.org/10.7150/ijbs.45221

9. Puspitasari I, Sinuraya L, Sinuraya R, Abdulah $\mathrm{R}$, Koyama H. Knowledge, attitude, and practice during the COVID-19 pandemic: a review. J Multidiscip Healthc. 2020 Jul; 13:727-33. 
https://doi.org/https://doi.org/10.2147/JMDH.S26 $\underline{5527}$

10. Alzoubi H, Alnawaiseh N, Al-Mnayyis A, AbuLubad M, Aqel A, Al-Shagahin H. COVID-19 knowledge, attitude and practice among medical and non-medical university students in Jordan. $J$ Pure Appl Microbiol. 2020; 14:17-24.

https://doi.org/10.22207/JPAM.14.1.04.

11. Huynh G, Nguyen TN, Tran VK, Vo KN, Vo VT, Pham LA. Knowledge and attitude toward COVID-19 among healthcare workers at District 2 Hospital, Ho Chi Minh City. Asian Pac J Trop Med. 2020; 13:260-265

https://doi.org/10.4103/1995-7645.280396

12. Farhana KM, Mannan KA. Knowledge and perception towards novel coronavirus (COVID 19) in Bangladesh, International Research Journal of Business and Social Science. 2020 Apr; 6(2): 76-87. https://doi.org/10.2139/ssrn.3576523.

13. Taghrir MH, Borazjani R, Shirali R. COVID-19 and Iranian medical students; A survey on their related-knowledge, preventive behaviors and risk perception. Arch. Iran. Med. 2020 Apr; 23(4):249-254.

https://doi.org/10.34172/aim.2020.06

14. Maheshwari S, Gupta PK, Sinha R, Rawat P. Knowledge, attitude, and practice towards coronavirus disease 2019 (COVID-19) among medical students: A cross-sectional study. J Acute Dis. 2020; 9(3):100-4. https://doi.org/10.4103/2221-6189.283886

15. Khalil NS, Al-Yuzbaki RS, Tawfeeq DB. COVID-19 knowledge, attitude and practice among medical undergraduate students in Baghdad City, Eurasia J Biosci. 2020; 14(2):4179-4186.

16. Zhang M, Zhou M, Tang F, Wang Y, Nie H, Zhang L. Knowledge, attitude, and practice regarding COVID-19 among healthcare workers in Henan, China. J. Hosp. Infect. 2020 Jun; 105 (2):183-7. https://doi.org/10.1016/j.jhin.2020.04.012 